\title{
Age, growth, and reproductive aspects of the dusky grouper Mycteroperca marginata (Actinopterygii: Epinephelidae) in a man-made rocky habitat in southern Brazil
}

\author{
Elisa Seyboth ${ }^{1}$, Mario V. Condini ${ }^{1}$, Cristiano Q. Albuquerque ${ }^{2}$, Antônio S. Varela Jr. ${ }^{1}$, \\ Gonzalo Velasco ${ }^{1}$, João P. Vieira ${ }^{1}$ and Alexandre M. Garcia ${ }^{1}$
}

\begin{abstract}
The dusky grouper, Mycteroperca marginata, is an important commercial marine fish that is currently considered an endangered species worldwide and listed as overexploited in Brazil. Although its reproductive biology has been studied elsewhere, no information is available for populations in its southernmost distribution limit on the Brazilian coast. The present work investigates age structure, growth and reproduction of individuals inhabiting a pair of rocky jetties, about $4.5 \mathrm{~km}$ long each, located in the mouth of Patos Lagoon in the municipality of Rio Grande, in the southwestern Atlantic Ocean. A total of 130 individuals obtained between February 2007 and May 2009 were analyzed, with total length ranging from 260 to $800 \mathrm{~mm}$. The growth coefficient found in the present study $(\mathrm{K}: 0.069)$ was lower than values reported for dusky grouper populations from the Mediterranean Sea (0.087) and southeast Africa (0.09). This difference could be related to higher average water temperatures in these regions compared to the current study site or due to poorer habitat quality in terms of the shelters available for dusky grouper individuals to establish their territories. Microscopic ovarian analyses of individuals during three years of sampling revealed only the occurrence of immature and resting females. The absence of ripe or post-spawning individuals, associated with low GSI values $(<0.2)$ over the studied months, indicates that the dusky grouper did not use this man-made rocky substrate as a spawning site. The current $\mathrm{L}_{50}$ estimate of $451.3 \mathrm{~mm}$ indicates that most individuals captured in this area are immature. Such fishing pressure on immature specimens, associated with its slow growth rates and complex reproductive characteristics, threatens sustainability of the current dusky grouper fishery at the study site.
\end{abstract}

A garoupa-verdadeira, Mycteroperca marginata, é uma espécie de importância comercial que atualmente é considerada como ameaçada mundialmente e sobre-explotada no Brasil. Embora sua biologia reprodutiva tenha sido estudada em outras regiões, nenhuma informação está disponível sobre populações que habitam o extremo sul da sua distribuição na costa brasileira. $\mathrm{O}$ presente trabalho investiga a estrutura de idade, crescimento e reprodução de indivíduos que habitam dois molhes de pedra, com cerca de 4,5 km de extensão cada, localizados na desembocadura da laguna dos Patos no município de Rio Grande, no Atlântico Sudoeste. Foram analisados 130 indivíduos obtidos entre fevereiro de 2007 e maio de 2009, com comprimento total entre 260 e $800 \mathrm{~mm}$. O coeficiente de crescimento no presente estudo $(\mathrm{K}: 0,069)$ foi inferior aos valores reportados para o Mediterrâneo $(0,087)$ e sudeste da África $(0,09)$. Essa diferença pode estar relacionada a temperaturas médias maiores nessas regiões comparadas ao presente local de estudo ou devido a menor qualidade de habitat em termo de abrigos para os indivíduos de garoupa-verdadeira estabelecerem seus territórios. Análises microscópicas dos ovários dos indivíduos durante esses três anos de amostragens revelaram somente a ocorrência de indivíduos imaturos e fêmeas em repouso. A ausência de indivíduos ovados ou em pós-desova, associada com baixos valores do IGS $(<0,2)$, ao longo de todos os meses de coleta, indica que a garoupa-verdadeira não utiliza esse substrato rochoso construído pelo homem como um local de desova. A estimativa de um $\mathrm{L}_{50}$ de $451,3 \mathrm{~mm}$ indica que a maioria dos indivíduos capturados nessa região é imatura. Pressão de pesca sobre indivíduos imaturos, associada com a sua lenta taxa de crescimento e complexo modo reprodutivo, ameaça a sustentabilidade da atual pesca da garoupa-verdadeira na área de estudo.

Key words: Endangered species, Epinephelus marginatus, Patos Lagoon, Rocky jetties.

\footnotetext{
${ }^{1}$ Universidade Federal do Rio Grande, Instituto de Oceanografia, Laboratório de Ictiologia, CP 474, 96201-900 Rio Grande, RS, Brazil. elisaseyboth@hotmail.com; amgarcia@mikrus.com.br

${ }^{2}$ Universidade Federal do Espírito Santo, Departamento de Oceanografia e Ecologia, 29075-090 Espírito Santo, RS, Brazil.
} 


\section{Introduction}

The dusky grouper Mycteroperca marginata (Actinopterygii, Epinephelidae), a new combination for Epinephelus marginatus according to Craig \& Hastings (2007), is an important commercial marine fish and is one of the most prized fish in the sport spearfishing, probably due its large body size, which can reach maximum values of $1.20 \mathrm{~m}$ and 60.0 Kg (Figueiredo \& Menezes, 1980; Heemstra \& Randall, 1993). It is usually found in relatively shallow waters $(<80 \mathrm{~m})$, occurring on both sides of Atlantic Ocean throughout the Mediterranean Sea and round the southern tip of Africa to southern Mozambique and Madagascar (Heemstra \& Randall, 1993). In the western Atlantic, its range is restricted to the coast of South America, from Rio de Janeiro southwards to Argentina (Figueiredo \& Menezes, 1980; Rico \& Acha, 2003; Luiz Jr. et al., 2004). The 'Molhes da Barra de Rio Grande' (MBRG), a man-made rock substrate (rocky jetty), $4.5 \mathrm{~km}$ long, located in the municipality of Rio Grande (southern Brazil) connecting a large coastal lagoon to the Atlantic Ocean, probably constitutes the southernmost limit of this species along the Brazilian coast (Condini et al., 2007).

Like other Serranidae species, the dusky grouper is characterized by slow growth, sedentary and territorial behavior, and a complex reproductive strategy (protogynous hermaphroditism) (Chauvét, 1991; La Mesa et al., 2002; Andrade et al., 2003; Fennessy, 2006). These biological features make this species particularly vulnerable to anthropogenic threats like increasing fishing pressure (Manooch, 1987; Falcón et al., 1996; Cornish \& HarmelinVivien, 2004). Not surprisingly, the dusky grouper is currently considered as an endangered species worldwide by the International Union for Conservation of Nature (IUCN) (Cornish \& Harmelin-Vivien, 2004) and is listed as overexploited in Brazil (Brasil, 2004).

Although several aspects of its biology and reproductive behavior are already known for populations from the Mediterranean Sea, west African coast (Heemstra \& Randall, 1993; Marino et al., 2001; Linde et al., 2004; Fennessy, 2006; Reñones et al., 2007) and southeastern Brazil (Andrade et al., 2003; Gerhardinger et al., 2006; Machado et al., 2008), no information is available for populations occurring in the southernmost region of its austral distribution in the Western Atlantic. Prior studies with the dusky grouper in this region are basically restricted to fishery statistics (Haimovici et al., 1994), descriptions of the socioeconomic profile and the fishing method employed by local artisanal fishermen (Condini et al., 2007), with no available information regarding its age structure and reproductive biology. The absence of information regarding biological parameters related to their growth (e.g. growth coefficient $\mathrm{K}$ ) and reproduction (e.g. length-at-first maturation $\mathrm{L}_{50}$ ) can hinder the local elaboration of fishery regulation and conservation plans. Although such parameters are available for dusky grouper populations occurring at tropical and temperate latitudes, their application in subtropical populations is not straightforward due to many factors related to site-specific differences in the environmental factors influencing these parameters (King, 1995). Therefore, it is important to know such biological aspects locally or regionally in order to provide precise information to guide fishery management and conservation plans for this endangered marine species. To provide this information and to expand the current knowledge of crucial aspects of the biology of the dusky grouper in its southernmost distribution limit on the Brazilian coast, the present work investigates age structure, growth and reproduction of individuals inhabiting a $4.5 \mathrm{~km}$ long pair of rocky jetties located in the southwestern Atlantic Ocean.

\section{Material and Methods}

\section{Study area and fish collection}

The $4.5 \mathrm{~km}$ long rocky jetties of 'Molhes da Barra de Rio Grande' (MBRG) were built in the beginning of the $20^{\text {th }}$ century with large pieces of rock ( 10 ton each) in the mouth of Patos Lagoon, a large subtropical coastal lagoon $\left(\sim 10,000 \mathrm{~km}^{2}\right)$ that empties into the Atlantic Ocean (32 $\left.09^{\prime} 38^{\prime \prime} \mathrm{S} ; 52^{\circ} 05^{\prime} 54^{\prime \prime} \mathrm{W}\right)$ (Fig. 1). Its main purpose was to maintain a navigation channel to guarantee regular maritime access to the international harbor of Rio Grande (southern Brazil). Beside its logistic and strategic importance to the economy of this region, MBRG constitutes a man-made rocky habitat harboring a diverse marine benthic fauna (Capítoli, 1996). It harbors also an abundant population of dusky grouper $M$. marginata (Condini et al., 2007). Although precise scientific records are not available, historical accounts obtained from local fishermen suggested that this species has been caught in MBRG at least since the 1970s.

Mycteroperca marginata specimens were obtained between February 2007 and May 2009 by experimental sampling or directly from local fishers. In both cases, individuals were caught using hook and line following the procedures described in Condini et al. (2011). There were no individuals captured during austral winter and early spring (June to November), probably due to the harsh conditions that usual prevail during these months. This period is characterized by a higher frequency of cold fronts, with wind velocities ranging from 16 to $24 \mathrm{~ms}^{-1}$ from S, SW and SE directions (Braga \& Krusche, 2000), which could disfavor capture of the dusky grouper at MBRG during this time of the year. In the field, individuals were preserved on ice and later stored in a freezer after their arrival in the laboratory. After being thawed, each individual had its total length (mm) and weight ( $\mathrm{g}$ ) measured. Voucher specimens were deposited in the ichthyological collection of the Universidade Federal do Rio Grande (FURG), registered under the number FURG 2657 (6): Molhe Oeste da Barra de Rio Grande, RS, Brazil; 6 Jan 2009.

\section{Age and growth determination}

The sagittae otolith from the right side of the head of each specimen was removed, cleaned and embedded in resin and sectioned ( $\sim 0.5 \mathrm{~mm}$ thick sections) through the core of each otolith using an ISOMET low speed saw. The sections were placed in a Petri dish filled with water, and examined 

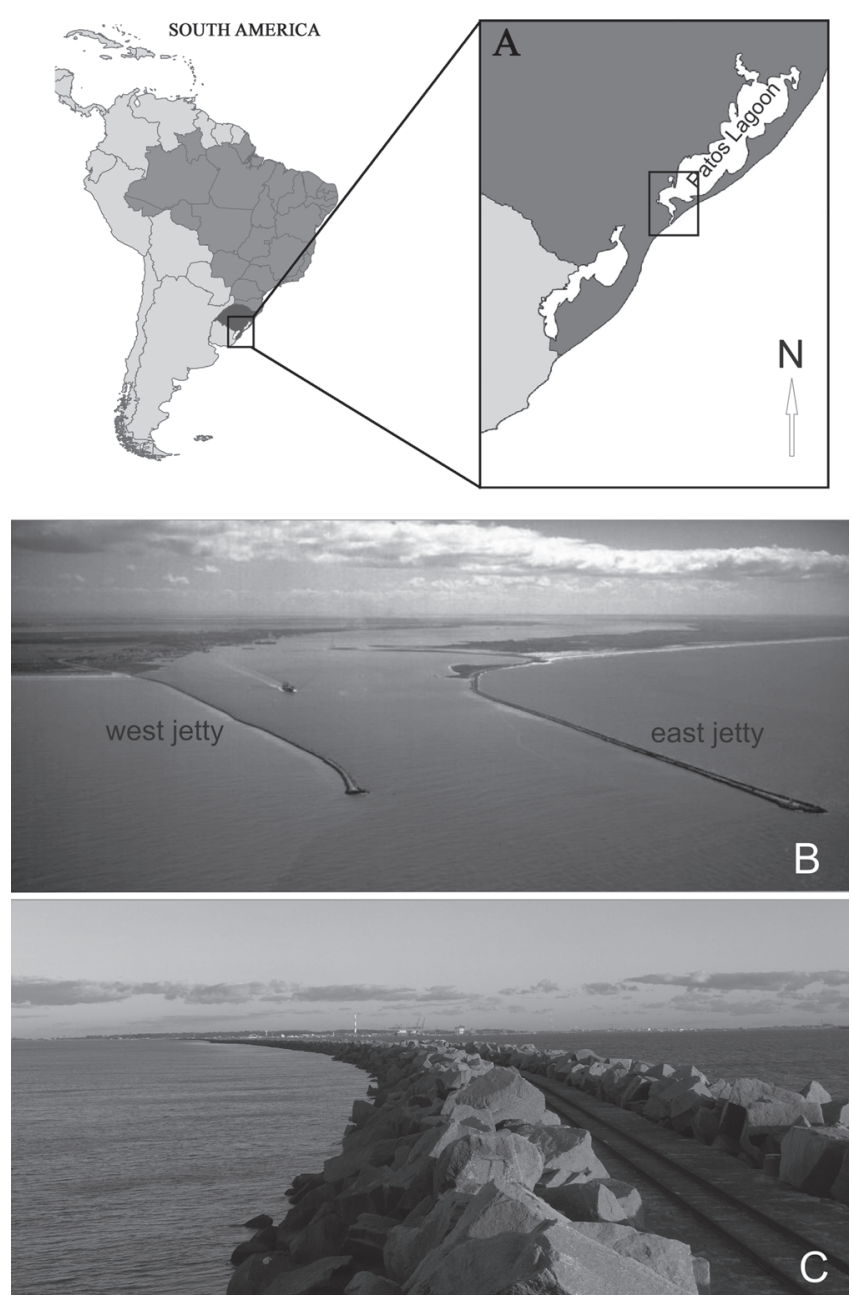

Fig. 1. A) Patos Lagoon $\left(10.360 \mathrm{~km}^{2}\right)$ in southern Brazil and B) the $4.5 \mathrm{~km}$ long pair of rocky jetties that connect the estuarine zone of Patos Lagoon to the Atlantic Ocean. C) A detail of the west jetty and its large pieces of rock (nearly 10 ton each), located in the municipality of Rio Grande (Rio Grande do Sul state) in southern Brazil.

using transmitted light under a dissecting microscope at 1530X magnification. The number of opaque bands in each otolith was counted separately and independently by three different readers without previous knowledge on length and weight of each fish. Precision of the age readings was assessed using an index of average percentage error (APE) (Campana, 2001). The annual rate of growth rings deposition was already established for M. marginata (Fennessy, 2006) and several congeneric species (Bullock et al., 1992; Bush et al., 1996; Potts \& Monooch, 1999). Therefore, we assumed that each growth ring (translucent + opaque band) represent one year in the present study.

Growth parameters for the studied dusky grouper population were obtained fitting the von Bertalanffy growth model, $\mathrm{Lt}=\mathrm{L}_{\infty}\left(1-\operatorname{EXP}\left(-\mathrm{K}\left(\mathrm{t}-\mathrm{t}_{0}\right)\right)\right)$ to the length-at-age data. In this model, $\mathrm{Lt}$ is the mean length at time $\mathrm{t}, \mathrm{L}_{\infty}$ the asymptotic length, $\mathrm{K}$ the growth coefficient and $\mathrm{t}_{0}$ the theoretical age at zero length. The $\mathrm{L}_{\infty}$ estimated based on our collected specimens was $3.967 \mathrm{~mm}$. This value is almost four folds higher compared to values reported in the literature. Such incongruence is probably related with the low number of large individuals in our dataset. It is known that the absence of larger individuals could preclude coherent estimation of the asymptotic length $\left(\mathrm{L}_{\infty}\right)$ (King, 1985). For that reason, we chose the value of $1.249 \mathrm{~mm}$ for $\mathrm{L}_{\infty}$, which was estimated by Fennessy (2006) based on a more representative data-set encompassing larger individuals. The parameters $\mathrm{t}_{0}$ and $\mathrm{K}$ were estimated by an iterative least squares procedure. Growth performance index (GP) was estimated using the equation $\mathrm{GP}=\log \mathrm{k}+2 \log \mathrm{L}_{\infty}$ (Pauly \& Munro, 1984), where K is the growth coeficient and $\mathrm{L}_{\infty}$ is the asymptotic length.

\section{Reproduction}

Each caught individual had its gonads extracted, weighed $(0.01 \mathrm{~g})$ and preserved in $10 \%$ formalin for 7 days and later stored in $70 \%$ alcohol for later histological processing. Six thin $(\sim 3 \mathrm{~mm})$ cross-sections of each gonad were taken from just posterior to the midsection of the gonad. These sections were dehydrated in an alcohol series, embedded in paraffin wax and sectioned transversely at $4-6 \mu \mathrm{m}$, and three sections were stained with haemotoxylin-eosin and the other three with Mallory's trichrome. These sections were later microscopically analyzed in order to assign sex and gonad maturity stages to each gonad based on the most developed stages of germ cells development and their relative proportions within the gonad, following modifications of classifications adopted by Marino et al. (2001).

Length-at-50\% maturity of females was obtained from a logistic equation following the procedures described in King (1995) and Vazzoler (1996) and based on the equation $y=1 /(1$ $+(\exp (-a+b) T L)$, where $y$ is the proportion of mature females in each size class and TL is the total length of each size class analysed. Since we did not observe any mature female, we used the proportion of resting females instead of the proportion of mature females, assuming that the resting phase comes after at least one oviposition. The parameters ' $a$ ' and ' $b$ ' were estimated by a nonlinear least square iterative procedure based on the Gauss-Newton algorithm.

The gonadosomatic index (GSI) was calculated as GSI $=$ (GW / (TW - GW)), where GW is the gonad weight (g) and TW is the total fish weight (g). Temporal variations in the GSI over the study period were evaluated based on monthly average values (Vazzoler, 1996). Differences among average GSI values in each period $(2007,2008,2009)$ were evaluated using one-way ANOVA. Assumptions of normality and heterogeneity of variance were analyzed by KolmogorovSmirnov and Cochran tests, respectively (Zar, 1994).

\section{Results}

Out of the 130 individuals analyzed, 81 were collected in the austral summer, 43 in autumn and 6 during spring months. 
No individual was caught during winter months. Total length ranged from 260 to $800 \mathrm{~mm}$ with an average value of $443 \mathrm{~mm} \pm$ $100.7 \mathrm{~mm}$. A total of 108 otoliths showed clear distinction between opaque and translucent bands (Fig. 2), with an average percentage error (APE) among readers of $7.9 \%$. Age determination revealed that individuals ranged from 2 to 12 years old, with most of them (54\%) being 4 to 5 years old (Fig. 3 ). The growth parameters estimated by the von Bertalanffy growth model in the present study were K: 0.069 and $\mathrm{t}_{0}:-1.49$ yrs (Fig. 4, Table 1). The growth performance index was estimated in 3.03 , similarly to other dusky groupers from different studies (Table 1).

The analysis of histological sections of gonads from 111 individuals revealed that only females inhabit MBRG (Fig. 5). Regarding sexual development stages, no individuals in sexual reversion were observed, but only immature (52.25\%) and resting females $(47.75 \%)$. The age of immature individuals ranged from 2 - 6 yrs; whereas for mature resting females ages ranged from $4-12 \mathrm{yrs}$. The length at which $50 \%$ of the females were mature was estimated at $451.3 \mathrm{~mm}$ (Fig. 6), which corresponded to an individual weighing approximately 1.7 $\mathrm{Kg}$. Females in the resting stage appeared after $400 \mathrm{~mm}$ of TL and no more immature individuals were observed after 600 mm (Fig. 7).

Average monthly values of the gonadosomatic index remained lower than 0.2 over the three studied periods (2007, 2008 and 2009) and, regardless of the period, there were no differences in average GSI values among months (2007: $\mathrm{F}(3 ; 18)=0.32, \mathrm{p}>0.81 ; 2008: \mathrm{F}(5 ; 39)=1.03, \mathrm{p}>0.41 ; 2009$ : $\mathrm{F}(2 ; 25)=0.33, \mathrm{p}>0.72)($ Fig. 8$)$.

\section{Discussion}

\section{Age and growth parameters}

The growth coefficient found in the present study (K: 0.069) was lower than values reported for dusky grouper populations from the Mediterranean Sea (0.08 in Bouchereau et al., 1999; 0.087 in Reñones et al., 2007) and southeast Africa (0.09 in Fennessy, 2006). This difference could be related to higher average water temperatures in these regions

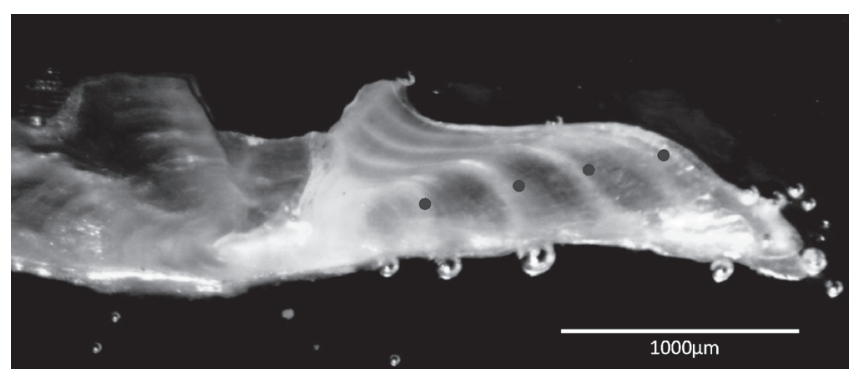

Fig. 2. Transverse section of an otolith of a $4+$ year-old dusky grouper (Mycteroperca marginata) collected in the study area. The photograph was taken under a stereomicroscope (20x) and reflected light, and shows a clear differentiation between opaque (white) and translucent (dark) growth bands.

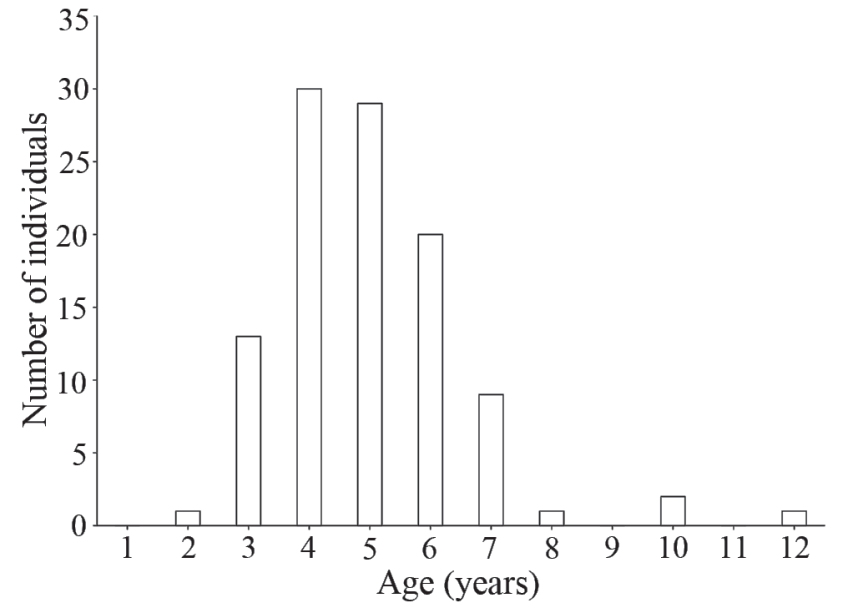

Fig. 3. Age absolute frequency for the dusky grouper (Mycteroperca marginata) collected in the study area. $\mathrm{n}=108$.

compared to the current study site. For instance, Fennessy (2006) investigated a dusky grouper population inhabiting the Kwazulu-Natal coast in southeast Africa, a region that is strongly influenced by the warmer waters from the Agulhas current (Bolton et al., 2004). In contrast, the southwestern Atlantic is characterized by the convergence of the Brazil and Malvinas currents, which carry warm and cold waters into this region, respectively. Such convergence produces a sharp gradient in temperature and salinity that change seasonally (Garcia, 1997; Brandini et al., 2000) and could negatively influence the growth rates observed in our study. Long-term records (1996-2010) of water temperatures measured monthly in the surf zone adjacent to our study site (MBRG) reveal that temperature can drop to $10^{\circ} \mathrm{C}$ during austral winter. Hence, regional differences on seawater temperature, associated with distinct oceanographic conditions between the southeast Africa coastline and the southwest Atlantic Ocean, could explain the relatively lower values in the growth coefficient $(\mathrm{K})$ observed in the present study.

Beyond the effect of temperature, the low growth rates estimated in the present study could be related to differences in habitat quality. In contrast with other studies conducted in natural reefs and rocky habitats (Bouchereau et al., 1999; Fennessy, 2006; Reñones et al., 2007), we investigated a population inhabiting a man-made rocky substrate that could have lower quality, for example, in terms of adequate number and/or size of shelters (crevices between rocks) available for dusky grouper individuals to establish their territories. As pointed out by Gibran (2007), shelter size is a key factor structuring dusk grouper populations in natural habitats. Future underwater surveys would be necessary to evaluate this habitat quality hypothesis. Despite comparisons of fish growth between different studies are usually based on the evaluation of growth rates $(\mathrm{K})$, their validity has been questioned since $\mathrm{K}$ and $\mathrm{L}_{\infty}$ are intrinsically and inversely correlated parameters. Therefore, it has been proposed that 


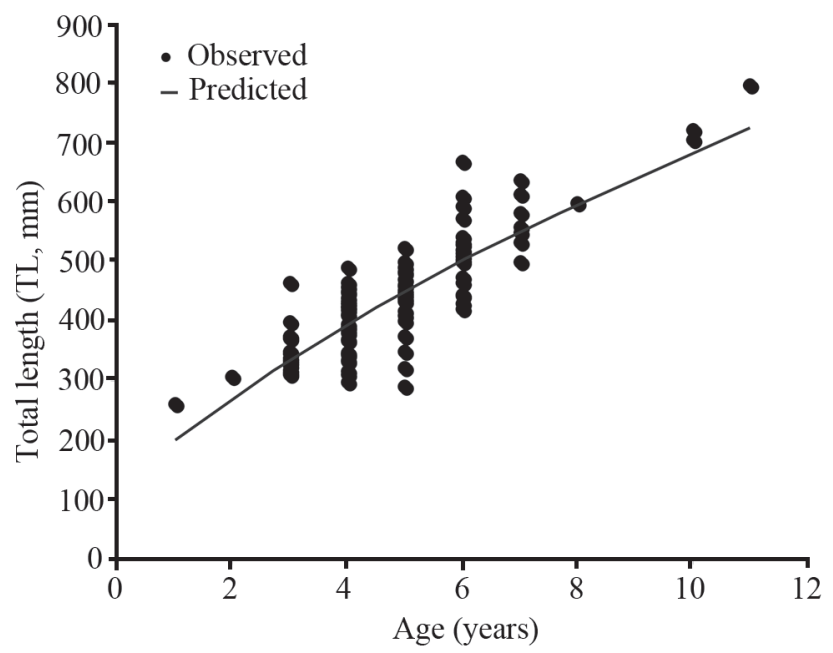

Fig. 4. von Bertalanffy growth curve fitted to age-at-length data for dusky grouper specimens (Mycteroperca marginata) collected in the study area $\left(\mathrm{K}=0.069 \mathrm{e} \mathrm{L}_{\infty}=1249 \mathrm{~mm}\right) . \mathrm{n}=108$.

an index of growth performance could be estimated to allow these comparisons (Pauly \& Munro, 1984). The growth performance index estimated for the dusky grouper inhabiting MBRG (GP: 3.03) suggest a similar growth pattern with dusky groupers from other studies (see Table 1).

The oldest individual found in the present study was 12 years old. Other studies, however, have found 16-year-old (Fennessy, 2006) and 61-year-old (Reñones et al., 2007) specimens. The absence of older individuals at our study site may be a consequence of fishing that could selectively remove larger (and older) individuals from the population (Ricker, 1969). Condini et al. (2007) have shown some evidence of increasing fishing effort by artisanal fisherfolks in MBRG in the last decades. Alternatively, the lack or the restricted number of larger shelters (pointed out earlier) could hinder the occurrence of larger specimens in MBRG.

\section{Reproductive aspects}

Microscopic ovarian analyses of individuals caught in MBRG during three years of sampling revealed the occurrence of only immature and resting females, with no occurrence of ripe females or males. Additionally, the gonadosomatic index (GSI) remained lower than 0.2 over the whole study period. In contrast, similar studies on the coastline of Kwazulu-Natal (southeast Africa) have shown GSI values changing from approximately 0.2 to 3.0 , with
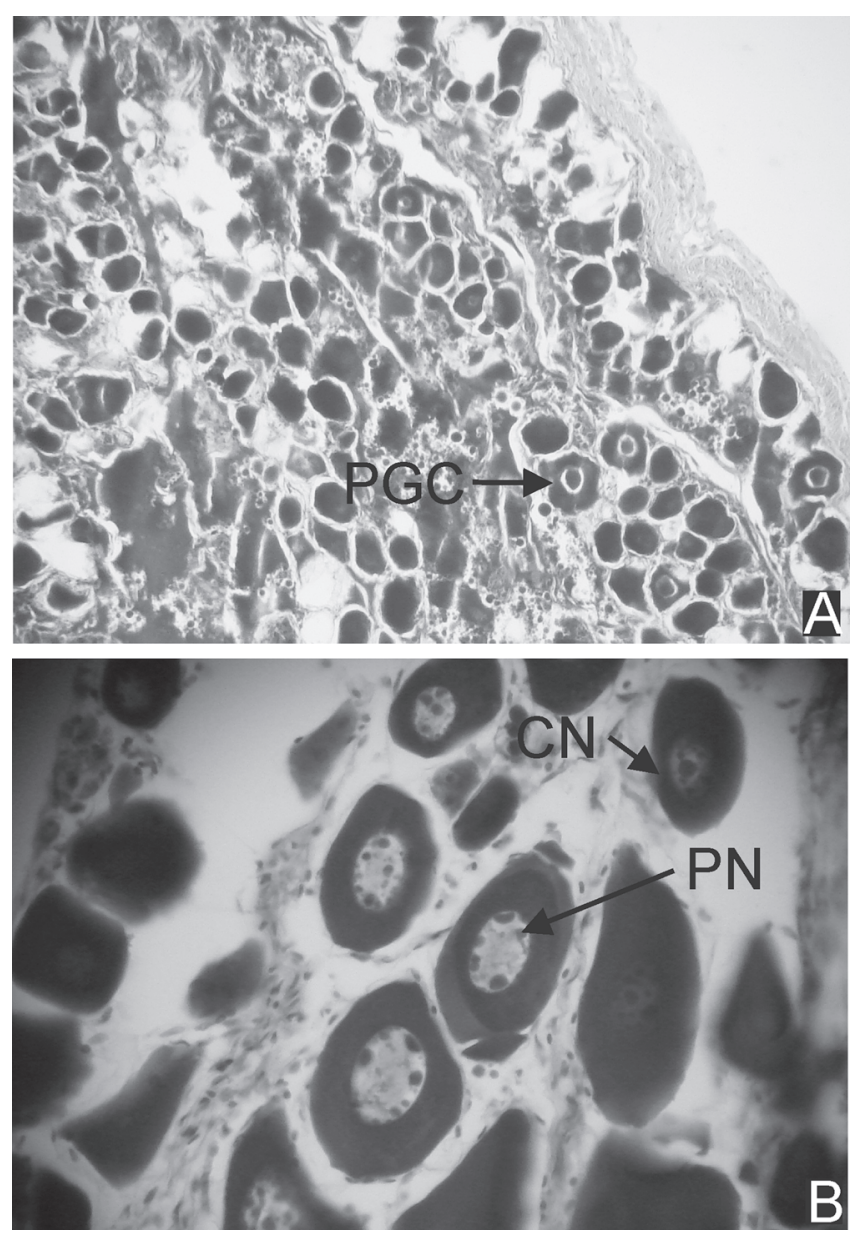

Fig. 5. Ovary sections of the dusky grouper (Mycteroperca marginata) collected in the study area. A) Immature gonad showing several primary germ cells (PGC) and oogonia. B) Resting gonad with small previtellogenic oocytes in chromatin nucleolus stage $(\mathrm{CN})$ and in perinucleolar stage $(\mathrm{PN})$.

higher values ( $>1.5$ ) in warmer months (Fenessy, 2006). Such increase in the GSI during warmer months, associated with the occurrence of ripe and post-spawning females, as well as ripe males, led the author to conclude that the species spawn during spring and summer in this region (Fennessy, 2006). Marino et al. (2001) has also reported average GSI values ranging approximately from 0.2 to 2.5 , with higher values $(>1.5)$ indicating spawning activity during summer months. Recently, Reñones et al. (2010) described a similar reproductive pattern in exploited dusky grouper population from the western Mediterranean, with maximum GSI values

Table 1. Comparative estimates of von Bertalanffy $\mathrm{L}_{\infty}, \mathrm{t}_{0}$ and $\mathrm{K}$ parameters and the growth performance (GP) value obtained for dusky grouper populations worldwide and in the present study. ${ }^{*} \mathrm{~L}_{\infty}$ obtained from Fenessy (2006).

\begin{tabular}{|c|c|c|c|c|c|c|}
\hline & Study site & Coordinates & $\mathrm{L}_{\infty}$ & $\mathrm{K}$ & $t_{0}$ & GP \\
\hline Bouchereau et al. (1999) & France & 41²1'08’N 9¹4’28”'E & 1359 & 0.08 & -0.8 & 3.16 \\
\hline Fenessy (2006) & Southeast Africa & $28^{\circ} 24^{\prime} 04^{\prime \prime} \mathrm{S} 32^{\circ} 25^{\prime} 57^{\prime \prime} \mathrm{E}$ & 1249 & 0.09 & -1.43 & 3.14 \\
\hline Reñones et al. (2007) & Western Mediterranean & $38^{\circ} 24^{\prime} 02^{\prime \prime N} 9^{\circ} 09^{\prime} 38^{\prime \prime} \mathrm{E}$ & 955 & 0.087 & -1.12 & 2.89 \\
\hline Present study & Southern Western Atlantic & $32^{\circ} 09^{\prime} 38^{\prime \prime} \mathrm{S} 52^{\circ} 05^{\prime} 54^{\prime \prime} \mathrm{W}$ & *1249 & 0.069 & -1.49 & 3.03 \\
\hline
\end{tabular}




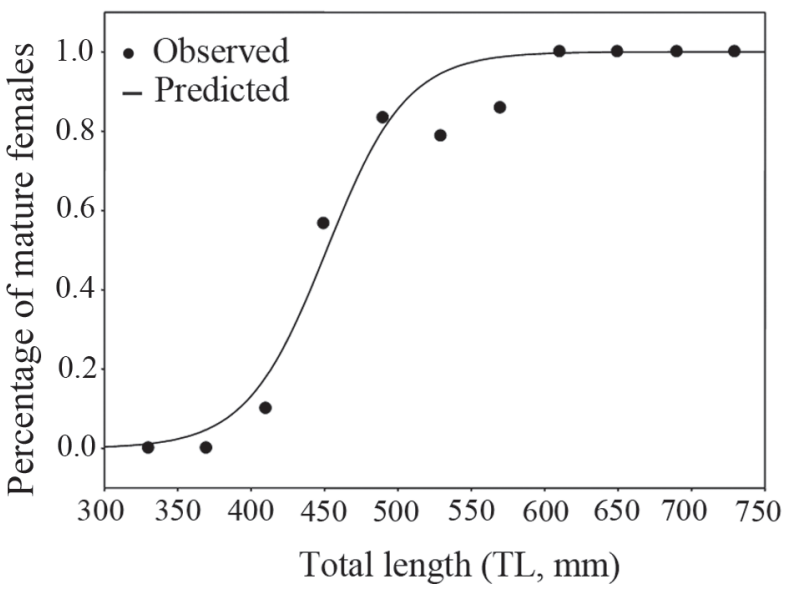

Fig. 6. Percentage of mature resting females for specimens of the dusky grouper (Mycteroperca marginata) collected in the study area by total length classes, fitted to a logistic function. $\mathrm{L}_{50}=451.3 \mathrm{~mm} . \mathrm{n}=111$.

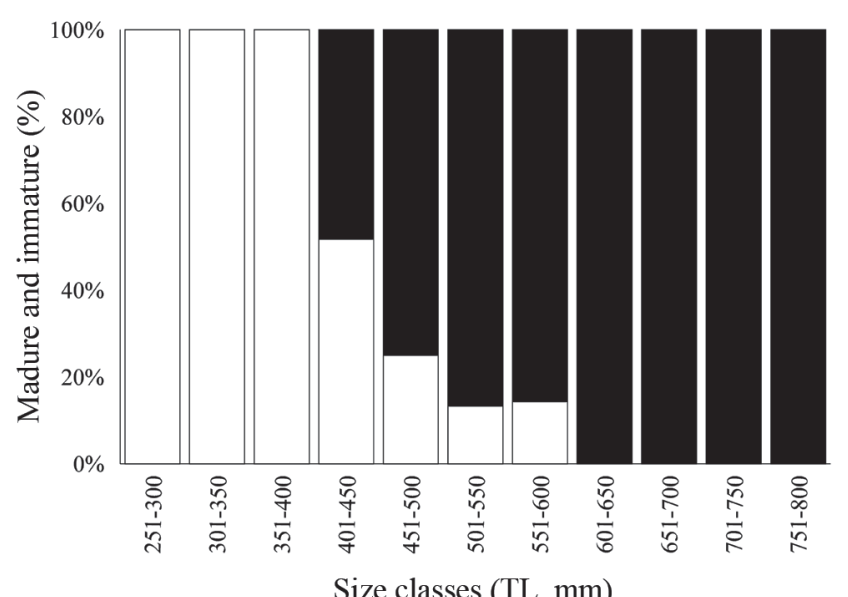

Fig. 7. Percentages of immature (white) and mature-resting females (black) per size classes (total length, mm) for Mycteroperca marginata individuals collected in the study area. $\mathrm{n}=111$.

over 2.0, indicating spawning activity during boreal summer months. In contrast with these studies, the absence of ripe or post-spawning individuals in MBRG, associated with low GSI values $(<0.2)$ over the entire studied period, suggest that the dusky grouper M. marginata found at MBRG did not use this man-made rocky substrate as a spawning site.

We hypothesize that spawning sites of this species in southern Brazil occur in natural rocky bottoms located in deeper waters along the coastline. Recent macroscopic observations made by the authors (E.S. and M.V.C) on gonads of individuals caught at a rocky bottom site located 16 miles east of MBRG (locally known as 'Parcel do Carpinteiro' or 'Carpinteiro Seamount') have shown the presence of ripe females and males. We speculate that mature resting females inhabiting MBRG

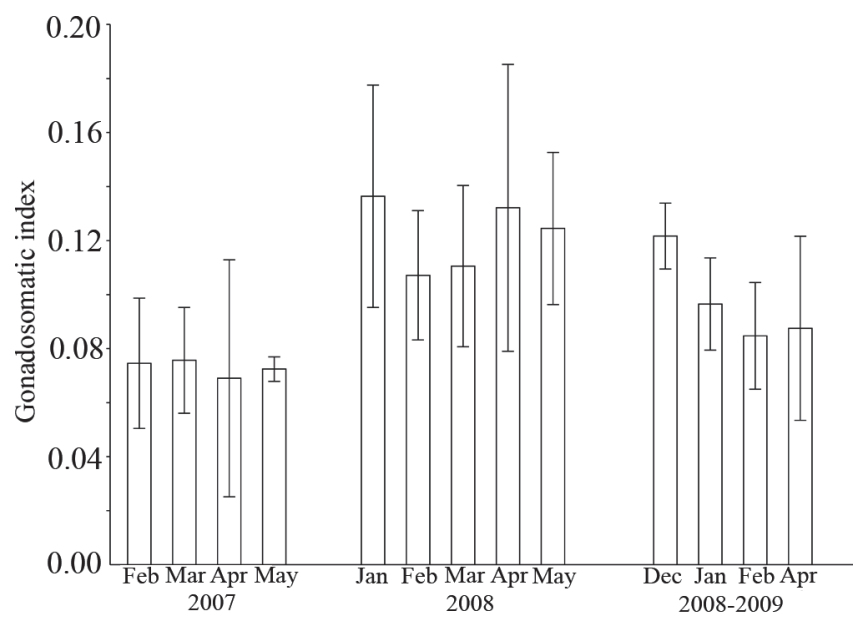

Fig. 8. Average monthly values (+ standard deviation) of the gonadosomatic index of the dusky grouper (Mycteroperca marginata) collected in the study area in 2007, 2008 and 2009. $n=105$.

migrate from this man-made rocky substrate to the natural offshore rocky bottoms for spawning. Reproductive aggregations of $M$. marginata close to Medes Islands (NW Mediterranean Sea), about two miles from the coast, suggest that this species is capable of such short migrations (Zabala et al., 1997).

Estimated mean length at first maturation $\left(\mathrm{L}_{50}\right)$ for females from $M B R G$ was $451.3 \mathrm{~mm}$. Previous $\mathrm{L}_{50}$ values reported for dusky grouper populations ranged from $438 \mathrm{~mm}$ in southern Mediterranean waters (Marino et al., 2001) to $622 \mathrm{~mm}$ on the southeastern African coast (Fennessy, 2006). Our estimated $\mathrm{L}_{50}$ can be considered similar to the $\mathrm{L}_{50}$ value of $470 \mathrm{~mm}$ reported for dusky groupers from the Arvoredo Biological Reserve $\left(27^{\circ} \mathrm{S}\right)$, located in southeast Brazil (Andrade et al., 2003). Apart from sampling differences and constraints, such $\mathrm{L}_{50}$ discrepancies could arise from distinct fishing pressure exerted upon dusky groupers in these areas, or simply the lack of larger individuals in MBRG. As previously demonstrated by Coleman et al. (1999), fishing pressure can promote the reduction of mean length at first maturation in serranids. Although long-term fishing pressure can potentially affect $\mathrm{L}_{50}$ values, we do not have enough fisheries data to compare southern Brazil to other areas where $M$. marginata is commercially exploited. These regional differences highlight the importance of estimating $\mathrm{L}_{50}$ in a local context to help decision makers adopt more effective management measures. Previous studies in the MBRG region have shown that most individuals caught by local fishermen in MBRG had relatively small sizes (median: $440 \mathrm{~mm}, \mathrm{TL}$ ) (Condini et al. 2007) and are likely immature. This fishing pressure on immature individuals, associated with the relatively slow growth rates and complex reproductive characteristics of this species, pose serious doubts about the sustainability of the current dusky grouper fishery at MBRG. Management actions should be considered in order to prevent overfishing in this stock. 


\section{Acknowledgements}

We thank technicians J. Cassemiro and M. Inês of the Histology Laboratory of the Instituto de Ciências Biológicas of the Universidade Federal de Rio Grande (FURG), who have assisted in the preparation of the histological sections, and local fishermen for their assistance in the field, as well as M. I. Militelli from INIDEP, Argentina, for suggestions on analysis of the gonads. The study received financial support from the Fundação O Boticário de Proteção a Natureza (0753-20072) and the Fundação de Amparo à Pesquisa do Estado do Rio Grande do Sul - FAPERGS (fellowship for E.S.).

\section{Literature Cited}

Andrade, A. B., L. F. Machado, M. Hostim-Silva \& J. P. Barreiros. 2003. Reproductive biology of the dusky grouper Epinephelus marginatus (Lowe, 1834). Brazilian Archives of Biology and Technology, 46: 373-381.

Bolton, J. J., F. Leliaert, O. de Clerck, R. J. Anderson, H. Stegenga, H. E. Engledow \& E. Coppejans. 2004. Where is the western limit of the tropical Indian Ocean seaweed flora? An analysis of intertidal seaweed biogeography on the east coast of South Africa. Marine Biology, 144: 51-59.

Bouchereau, J. L., P. Body \& C. Chauvét. 1999. Growth of the dusky grouper Epinephelus marginatus (Linnaeus, 1758) (Teleostei, Serranidae), in the Natural Marine Reserve of Lavezzi Islands, Corsica, France. Scientia Marina, 63: 71-77.

Braga, M. F. S. \& N. Krusche. 2000. Padrão de Ventos em Rio Grande, RS, no período de 1992 a 1995. Atlântica, 22: 27-40.

Brandini, F. P., D. Boltovskoy, A. Piola, S. Kocmur, R. Rottgers, P. C. Abreu \& R. M. Lopes. 2000. Multiannual trends in fronts and distribution of nutrients and chlorophyll in the southwestern Atlantic (30-62 ${ }^{\circ}$ S). Deep-Sea Research I, 47:1015-1033.

Brasil. 2004. Ministério do Meio Ambiente. Instituto Brasileiro do Meio Ambiente e dos Recursos Naturais Renováveis (IBAMA). Instrução Normativa ${ }^{\circ}$ 3. Ministério do Meio Ambiente, Brasília.

Bullock, L. H., M. D. Murphy, M. F. Godcharles \& M. Mitchell. 1992. Age, growth and reproduction of jewfish Epinephelus itajara in the eastern Gulf of Mexico. Fishery Bulletin, 90: 243-249.

Bush, P. G., G. C. Ebanks \& E. D. Lane. 1996. Validation of aging technique for Nassau grouper (Epinephelus striatus) in the Cayman Islands. Pp. 150-157. In: Arreguin-Sanchez F., J. L. Munro, M. C. Balgos \& D. Pauly (Eds). Proceedings of an EPOMEX/ICLARM International Workshop on Tropical Snappers and Groupers, October 1993, Campeche, Mexico. ICLARM, Manila, Philippines.

Campana, S. E. 2001. Accuracy, precision and quality control in age determination, including a review of the use and abuse of age validation methods. Journal of Fish Biology, 59: 197-242.

Capítoli, R. R. 1996. Rubble structures and hard substrates. Pp. 86-89a. In: Seeliger, U., C. Odebrecht \& J. P. Castello (Eds.). Subtropical Convergence Environments: The Coast and Sea In The Southwestern Atlantic. Berlim, Springer-Verlag, 308p.

Chauvét, C. 1991. Statut d'Epinephelus guaza (Linnaeus, 1758) et éléments de dynamyque des populations méditerranéen et atlantique. Pp. 255-275. In: Boudouresque, C. F., M. Avon \& V. Graves (Eds.). Les Espéces Marines a Proteger en Méditerranée. France, GIS Posidonie.
Coleman, F. C., C. C. Koenig, A. Eklund \& C. B. Grimes. 1999. Management and conservation of temperate reef fishes in the grouper-snapper complex of the southeastern United States. Pp. 233-242. In: Musick, J.A. (Eds.). Life in the Slow Lane: Ecology and Conservation of Long-lived Marine Animals. American Fisheries Society Symposium 23.

Condini, M. V., A. M. Garcia \& J. P. Vieira. 2007. Perfil do pescador e descrição da pesca da garoupa (Pisces, Serranidae) no Molhe Oeste da Barra de Rio Grande, RS. Pan-Americam Journal of Aquatic Sciences, 2: 279-287.

Condini, M. V., E. Seyboth, J. P. Vieira, A. M. Garcia. 2011. Diet and feeding strategy of the dusky grouper Mycteroperca marginata (Actinopterygii: Epinephelidae) in a man-made rocky habitat in southern Brazil. Neotropical Ichthyology, 9: 161-168.

Cornish, A. \& M. Harmelin-Vivien. 2004. Epinephelus marginatus. IUCN Red List of Threatened Species. Avaiable from: http:// www.iucnredlist.org/ (18 May 2007).

Craig, M. T. \& P. A. Hastings. 2007. A molecular phylogeny of the groupers of the subfamily Epinephelinae (Serranidae) with a revised classification of the Epinephelini. Ichthyological Research, 54: 1-17.

Falcón, M. J., S. A. Borbone, A. Brito \& C. M. Bundrick. 1996. Structure of and relationships within and between the littoral, rock-substrate fish communities off four islands in the Canarian Archipelago. Marine Biology, 125: 215-231.

Fennessy, S. T. 2006. Reproductive biology and growth of the yellowbelly rockcod Epinephelus marginatus (Serranidae) from South-East Africa. African Journal of Marine Science, 28: 1-11.

Figueiredo, J. L. \& N. A. Menezes. 1980. Manual de peixes marinhos do sudeste do Brasil. III. Teleostei (2). São Paulo, Museu de Zoologia, Universidade de São Paulo, 90p.

Garcia, C. A. E. 1997. Physical oceanography. Pp. 94-96. In: Seeliger, U., C. Odebrecht \& J. P. Castello (Eds.). Subtropical Convergence Environments: The Coast and Sea In The Southwestern Atlantic. Berlim, Springer-Verlag, 308p.

Gerhardinger, L. C., M. O. Freitas, A. A. Bertoncini \& M. HostimSilva. 2006. Collaborative approach in the study of the reproductive biology of the dusky grouper Epinephelus marginatus (Lowe, 1834) (Perciformes: Serranidae). Acta Scientiarum - Biological Sciences, 28: 219-226.

Gibran, F. Z. 2007. Activity, habitat use, feeding behavior, and diet of four sympatric species of Serranidae (Actinopterygii: Perciformes) in southeastern Brazil. Neotropical Ichthyology, 5: 387-398.

Haimovici, M., A. S. Martins, J. L. Figueiredo \& P. C. Vieira. 1994. Demersal bony fish of the outer shelf and upper slope of the southern Brazil subtropical convergence ecosystem. Marine Ecology Progress Series, 108: 59-77.

Heemstra, C. P. \& J. E. Randall. 1993. FAO Species catalogue. Groupers of the word (Family Serranidae, Subfamily Epinephelinae: An Annotated and Illustred Catalogue of the Grouper, Rockcod, Hind, Coral grouper Lyretail Species. FAO Fisheries Synopsis, 125: 186-189.

King, M. 1995. Fisheries biology, assessment and management. Fishing New Books, 341p.

La Mesa, G., P. Louisy \& M. Vacchi. 2002. Assessment of microhabitat preferences in juvenile dusky grouper (Epinephelus marginatus) by visual sampling. Marine Biology, 140: 175-185.

Linde, M., A. M. Grau, F. Riera \& E. Massutí-Pascual. 2004. Analysis of trophic ontogeny in Epinephelus marginatus (Serranidae). Cybium, 28: 27-35.

Luiz Jr., O. J., S. R. Floeter, C. E. L. Ferreira, J. L. Gasparini \& P. Wirtz. 2004. The occurrence of Acanthurus monroviae 
(Perciformes: Acanthuridae) in the southwestern Atlantic, with comments on other eastern Atlantic reef fishes occurring in Brazil. Journal of Fish Biology, 65: 1173-1179.

Machado, L. M., F. A. M. L. Daros, A. A. Bertoncini, M. HostimSilva \& J. P. Barreiros. 2008. Feeding strategy and trophic ontogeny in Epinephelus marginatus (Serranidae) from Southern Brazil. Cybium, 32: 33-41.

Manooch C. S. \& D. L. Mason. 1987. Age and growth of the Warsaw grouper and black grouper from the southeast region of the United States. Northeast Gulf Science, 9: 65-75.

Marino, G., E. Azzurro, A. Massari, M. G. Finoia \& A. Mandich. 2001. Reproduction in the dusky grouper from the southern Mediterranean. Journal of Fish Biology, 58: 909-927.

Potts, J. C. \& C. S. Manooch. 1999. Observations on the age and growth of graysby and coney from the southeastern United States. Transactions of the American Fisheries Society, 128: 751-757.

Reñones, O., A. Grau, X. Mas, F. Riera \& F. Saborido-Rey. 2010. Reproductive pattern of an exploited dusky grouper Epinephelus marginatus (Lowe 1834) (Pisces: Serranidae) population in the western Mediterranean. Scientia Marina, 74: 523-537.
Reñones, O., C. Piñeiro, X. Mas \& R. Goñi. 2007. Age and growth of the dusky grouper Epinephelus marginatus (Lowe 1834) in an exploited population of the western Mediterranean Sea. Journal of Fish Biology, 71: 346-362.

Ricker, W. E. 1969. Effects of size-selective mortality and sampling bias on estimates of growth, mortality, production and yield. Journal of the Fisheries Research Board of Canada, 26: 478-541.

Rico, M. R. \& E. M. Acha. 2003. Southernmost occurrence of Epinephelus marginatus in the south-west Atlantic. Journal of Fish Biology, 63: 1621-1624.

Vazzoler, A. E. A. M. 1996. Biologia da reprodução de peixes teleósteos: teoria e prática. Maringá, EDUEM, 169p.

Zabala, M., P. Louis, A. Garcia-Rubies \& V. Gracia. 1997. Sociobehavioural context of reproduction in the mediterranean dusky grouper Epinephelus marginatus (Lowe, 1834) (Pisces, Serranidae) in the Medes Islands Marine Reserve (NW Mediterranean, Spain). Scientia Marina, 61: 79-89.

Zar, J. H. 1994. Biostatistical analysis. $2^{\text {a }}$ ed. Prentice Hall, USA, $662 \mathrm{p}$.

Submitted October 20, 2010 Accepted September 13, 2011 Published December 26, 2011 